\title{
BRIEFLY NOTED
}

(Not reproduced in International Legal Materials)

\section{Judicial and Similar Proceedings}

1. Prosecutor v. Bemba and Others (International Criminal Court - September 17, 2018)

$<$ https://www.icc-cpi.int/Pages/record.aspx?docNo=ICC-01/05-01/13-2312>

On September 17, 2018, the International Criminal Court (ICC) Trial Chamber VII delivered its re-sentencing decision for Jean-Pierre Bemba Gombo, Aimé Kilolo Musamba, and Jean-Jacques Mangenda Kabongo, following the ICC Appeals Chamber judgment that had reversed the initial sentences against the men in March 2018. The Chamber "sentenced M. Bemba to one year imprisonment and fined him EUR 300,000. M. Kilolo and M. Mangenda were sentenced each to a total of 11 months of imprisonment. M. Kilolo was also fined EUR 30,000." Because of the time they had already spent in detention, the sentences were considered to have already been served and the fines were ordered to be paid within three months.

2. Lachiri v. Belgium (European Court of Human Rights - September 18, 2018)

$<$ http://hudoc.echr.coe.int/eng?i=001-186245>

On September 18, 2018, a Chamber of the European Court of Human Rights ruled in Lachiri v. Belgium that there had been a violation of Article 9 (freedom of thought, conscience and religion) of the European Convention on Human Rights when a woman was excluded from a courtroom after refusing to remove her hijab. The Court found that banning the woman, who was not a state representative, "had amounted to a 'restriction' on the exercise of her right to manifest her religion." While the Court held that the restriction pursued the legitimate aim of "protecting public order," the Court determined that the woman's conduct in the courtroom was respectful and not a threat to the proceedings, and consequently, "the need for the restriction in question had not been established and that the infringement of Mrs Lachiri's right to freedom to manifest her religion was not justified in a democratic society."

3. Wightman MSP and others v. Secretary of State for Exiting the EU (Scottish Court of Session - September 21, 2018)

$<$ http://www.scotcourts.gov.uk/docs/default-source/cos-general-docs/pdf-docs-for-opinions/2018csih62.pdf? sfvrsn $=0>$

On September 21, 2018, the highest court in Scotland, the Court of Session, ruled in Wightman MSP and others v. Secretary of State for Exiting the EUthat a judicial review question about whether the U.K.'s notice to leave the EU can be unilaterally revoked before the March 29, 2019, deadline, rather than be approved by all EU member states, should be answered by the Court of Justice of the European Union (CJEU). The Court decided that the question was not hypothetical or premature because U.K. members of parliament must ratify any agreement between the U.K. and the EU Council, and the Court found that it did not infringe on the boundaries of parliamentary privilege. The Court agreed to refer the case to the CJEU for a preliminary hearing, asking, "Where a Member State has notified the European Council of its intention to withdraw from the European Union, does EU law permit that notice to be revoked unilaterally by the notifying Member State; and, if so, subject to what conditions and with what effect relative to the Member State remaining within the EU?" 
4. Situation in the Gabonese Republic Article 5 Report (International Criminal Court-September 21, 2018)

$<$ https://www.icc-cpi.int/itemsDocuments/180921-otp-rep-gabon_ENG.pdf>

On September 21, 2018, the International Criminal Court (ICC) Prosecutor Fatou Bensouda decided to close the preliminary examination into the situation in Gabon. In September 2016, the government of Gabon sent the Office of the Prosecutor (OTP) a referral regarding alleged crimes that had been taking place in Gabon surrounding the presidential election since May 2016. In the referral, the Gabonese government "alleged that opposition leader and former presidential candidate, Mr. Jean Ping, incited his supporters to commit genocide during his 2016 presidential campaign" and that opposition supporters committed crimes in the aftermath of the presidential election's results announcement amounting to crimes against humanity. The Prosecutor decided to close the examination due to a lack of subject matter jurisdiction, concluding that there was no reasonable basis to believe that the 2016 post-election violence constituted crimes against humanity under the Rome Statute and the available information did not support the allegation of incitement to genocide during the election campaign.

5. Obligation to Negotiate Access to the Pacific Ocean (Bolivia v. Chile) (International Court of Justice October 1, 2018)

$<$ https://www.icj-cij.org/files/case-related/153/153-20181001-JUD-01-00-EN.pdf>

On October 1, 2018, the International Court of Justice ruled in Obligation to Negotiate Access to the Pacific Ocean (Bolivia v. Chile) that Chile was not obligated to negotiate sovereign access to the Pacific Ocean for Bolivia. Bolivia argued that Chile had an obligation to negotiate in order to reach an agreement giving Bolivia sovereign access to the ocean, citing several discussions between the states over a number of years that Bolivia argued showed Chile had bound itself to negotiations that would lead to the access point. Bolivia brought eight legal bases to support its claim: bilateral agreements; Chile's declarations and other unilateral acts; acquiescence; estoppel; legitimate expectations; provisions of the Charter of the Organization of American States (OAS); resolutions of the OAS General Assembly; and the cumulative effects of the instruments, acts, and conduct. The Court noted that the states "have a long history of dialogue, exchanges and negotiations aimed at identifying an appropriate solution to the landlocked situation of Bolivia following the War of the Pacific and the 1904 Peace Treaty," but found that Chile did not have "the obligation to negotiate with Bolivia in order to reach an agreement granting Bolivia a fully sovereign access to the Pacific Ocean.”

\section{Resolutions, Declarations, And Other Documents}

\section{Referral of Poland to the Court of Justice of the European Union (European Commission - September 24, 2018) \\ $<$ http://europa.eu/rapid/press-release_IP-18-5830_en.htm>}

On September 24, 2018, the European Commission referred Poland to the Court of Justice of the European Union in regard to a recent Polish law that lowers the retirement age of Supreme Court judges from seventy to sixty-five, which could force twenty-seven out of seventy-two sitting judges into retirement. The Commission argued that the law "undermines the principle of judicial independence, including the irremovability of judges, and thereby Poland fails to fulfil its obligations under Article 19(1) of the Treaty on European Union read in connection with Article 47 of the Charter of Fundamental Rights of the European Union." The move comes after the Commission launched infringement proceedings by sending a Letter of Formal Notice to Poland on the matter in July of 2018 and followed up with a Reasoned Opinion in August. The Commission has argued that the law "is being accelerated and is creating a risk of serious and irreparable damage to judicial independence in Poland, and therefore of the EU legal order." 
2. Resolution A/HRC/39/L.22 (Human Rights Council-September 28, 2018)

$<$ http://undocs.org/A/HRC/39/L.22>

On September 28, 2018, the UN Human Rights Council passed a resolution that calls for an independent mechanism to collect and analyze evidence in regard to the serious international crimes committed in Myanmar against Rohingya Muslims and other minorities since 2011. The resolution requests that the independent mechanism "prepare files in order to facilitate and expedite fair and independent criminal proceedings, in accordance with international law standards, in national, regional or international courts or tribunals that have or may in the future have jurisdiction over these crimes." The resolution also extends the mandate of the independent international fact-finding mission until the new mechanism is operational and "requests the United Nations High Commissioner for Human Rights to present a written report . . on the root causes of the human rights violations and abuses the Rohingya Muslim minority and other minorities in Myanmar are facing."

3. United States-Mexico-Canada Agreement (September 30, 2018)

$<$ https://ustr.gov/trade-agreements/free-trade-agreements/united-states-mexico-canada-agreement/agreementbetween>

On September 30, 2018, the United States, Mexico, and Canada reached an agreement in the renegotiation of the North American Free Trade Agreement (NAFTA) called the United States-Mexico-Canada Agreement (USMCA). Upon its ratification by the three states, the USMCA will replace NAFTA, which had been in effect since 1994. The USMCA makes a number of changes to NAFTA, some of the bigger areas being in relation to automobiles and country of origin rules, the daily industry, labor, the environment, intellectual property protections, and digital trade. The USMCA is also subject to review after six years and contains a sunset clause after sixteen years that will allow the states to renew it at that point.

4. Unearthing Atrocities: Mass Graves in Territory Formerly Controlled by ISIL (UN Assistance Mission for Iraq and the Office of the High Commissioner for Human Rights - November 6, 2018) $<$ https://www.ohchr.org/Documents/HRBodies/HRCouncil/FFM-Myanmar/A_HRC_39_64.pdf>

On November 6, 2018, the UN Assistance Mission for Iraq (UNAMI) and the Office of the High Commissioner for Human Rights (OHCHR) released a joint report entitled, "Unearthing Atrocities: Mass Graves in Territory Formerly Controlled by ISIL," which documents the discovery of an estimated 202 mass graves containing the remains of thousands of victims in areas formerly controlled by ISIL in Iraq. The report notes that an exact figure is difficult to determine, but that the smallest grave site found contained eight bodies, while the largest had thousands. It also highlights the difficulties Iraqi authorities face in conducting exhumations, investigations, and identifying remains, as well as the challenges family members face in obtaining information about missing persons. The Report further discusses Iraq's obligations under international law to investigate and prosecute the mass killings and discusses best practices for examining mass graves to collect evidence in support of criminal prosecution. UN High Commissioner for Human Rights, Michelle Bachelet's statement on the report: "These graves contain the remains of those mercilessly killed for not conforming to ISIL's twisted ideology and rule, including ethnic and religious minorities. Their families have the right to know what happened to their loved ones. Truth, justice and reparations are critical to ensuring a full reckoning for the atrocities committed by ISIL." 